DOI:10.17951/h.2017.51.2.59

\begin{tabular}{lcr}
\hline \multicolumn{3}{c}{ A N N A L E S } \\
UNIVERSITATIS MARIAE CURIE-SKŁODOWSKA \\
LUBLIN - POLONIA \\
VOL.LI, 2 & SECTIOH H \\
\hline
\end{tabular}

WSB University in Wrocław, Institute of Management and Marketing

AGNIESZKA DEJNAKA

agnieszka.dejnaka@wsb.wroclaw.pl

\title{
Technologization of Marketing Communication - New Trends
}

Technologizacja komunikacji marketingowej - nowe trendy

Key words: technologization of marketing; marketing communication; new trends in communication; chatbots; augmented reality; Internet of things

Słowa kluczowe: technologizacja marketingu; komunikacja marketingowa; nowe trendy w komunikacji; chatboty; rzeczywistość rozszerzona; Internet rzeczy

JEL codes: M31; M15

\section{Introduction}

The aim of marketing communication is to contact the enterprise with its market and to stimulate the selling process. Its message should be fitted to social, cultural, and technological changes that occur in the market. Therefore, in view of intense development of technology and information society, technologization of marketing communication seems natural.

Modern technologies change the world. More and more companies and corporations use them in marketing because they know that society follows everything what is innovative and best of all mobile. Consumers expect from products and services some added value, and enterprises compete in offering them new solutions and values. Information revolution and technical progress make the base of globalization process. Due to improved technical possibilities the appliances for mobile use are all the time modernized, innovative solutions appear that allow non-stop use of the network. Globalization process makes the borders diffuse and, thus, increases the sense of commu- 
nity among people, but at the same time creates barriers between generations. New technological products determine the development direction for subsequent generations, and the pace of changes forces tremendous elasticity of young people.

New trends prove technologization of marketing communication in various aspects and various ways of entering into relations with consumer. The most interesting with respect to marketing activities are: augmented reality (AR), QR codes, chatbots, and infographics.

\section{Augmented reality (AR)}

One of non-typical technologies being used in marketing activities is the augmented reality technology. This comparatively novel technology became in the last years one of the tools used in advertising or virtual presentation of products. Augmented reality (AR) is the area of information technology that connects the real world with the virtual elements, generated using the computer graphics ${ }^{1}$. AR does not create new, fully virtual 3D world, but extends and supplements the real world with new images (virtual overlayer). When using AR, the real world does not change, but is merely "extended" to include new objects or information. This extension can take the form of simple information "put over" onto the real world (street names, navigation information), or can be based on complicated photo-realistic objects that are incorporated into the real world forming self-contained whole (e.g. reconstructions of destroyed historical buildings, military simulations).

AR is the real picture with added virtual elements and allows for interactive motion. Special system that links together cameras and sensors recognizes elements located in the given territory and adds virtual information to this visible picture. In this way computer generated objects can be seen on the telephone or tabletscreen ${ }^{2}$.

Thanks to the AR technology, companies can replace the possibility to touch or even to try the product by consumers, supporting, therefore, the purchase process. The software is scanning the real image and links it with the products offered by the company on the given platform. In effect, the consumer sees the combined picture, like the product overlapping his/her own image or the image of a city. Alternatively, the user can see a three-dimensional product, look at it from every side and rotate with hand movement.

In AR, any marker (some tag that can be recognized by software, i.e. consumer's face) can be supplemented by the software with any content, object, virtual movie. This system is being applied in outdoor campaigns, but also in points of sale. In Po-

1 K. Bonsor, How Augmented Reality Will Work, http://computer.howstuffworks.com/augmented-reality.htm (access: 02.02.2017).

2 Augmented Reality and its use by ordinary users: http://www.newsfix.p1/2011/05/20/augmented-reality-i-jej-zastosowania-przez-zwyklych-uzytkownikow/ (access: 20.01.2017). 
land, AR utilization for marketing purposes is still rare, but in the world it develops faster and faster. AR can also add variety to any kind of events, fairs, or business meetings, as well as occasional parties ${ }^{3}$. Figure 1 presents the possibility to use AR in the point of sale - a shoe shop.

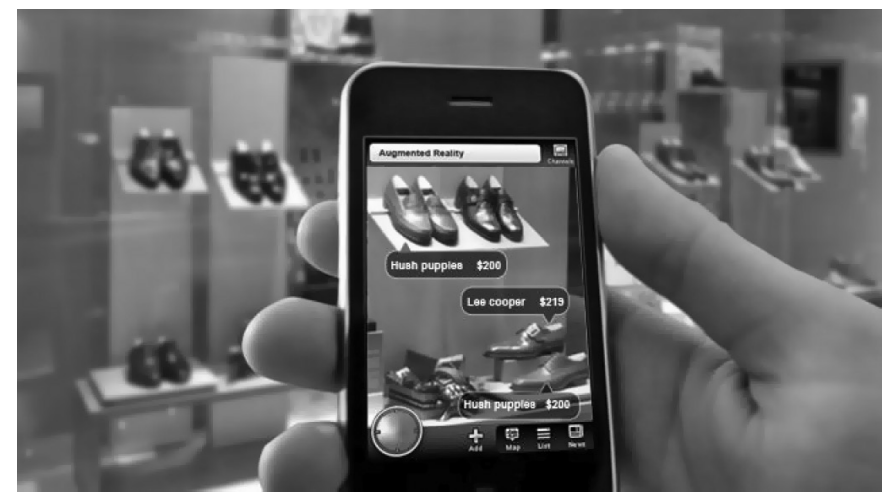

Figure 1. Augmented reality in the point of sale - a shoe shop

Source: http://www.augmentedrealitytrends.com/augmented-reality-retail/will-augmented-reality-change-the-future-ofretail-market-part-1.html (access: 17.02.2017).

Other AR applications in marketing can be presented on the example of IKEA, where AR allows one to see the furnished interior through the AR overlay with pieces of furniture being accessible in IKEA shops (Figure 2).

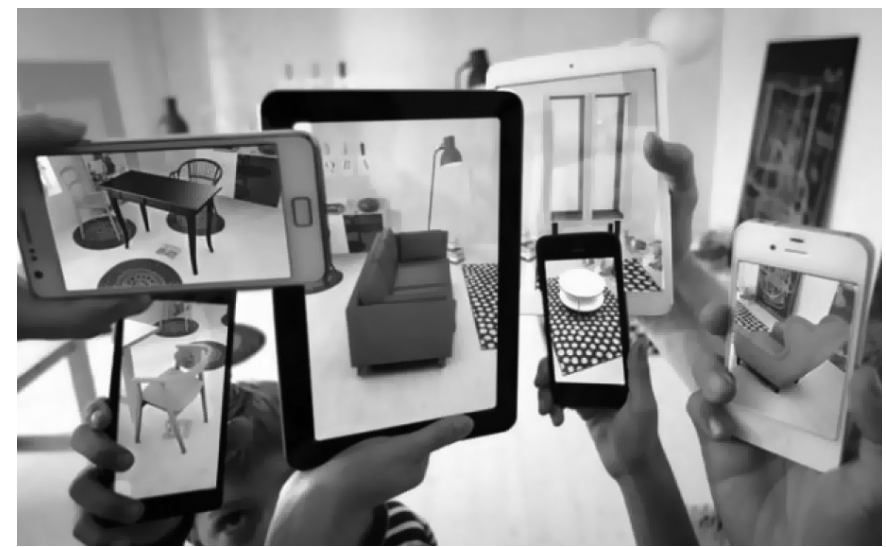

Figure 2. Augmented reality - IKEA

Source: http://www.dezeen.com/2013/08/05/ikea-launches-augmented-reality-catalogue/ (access: 17.02.2017)

\footnotetext{
3 Information on AR: http://www.salesnews.pl/SalesSupportArticle.aspx?id=32 (access: 17.02.2017).
} 
Using AR, IKEA gives the customers the visualization of interior arranged using the furniture from its catalogue. Thanks to such solution the customer has the possibility to select the fittings of interior in an ideal way. This application minimises also the problem of exchange or return of purchased goods, since the consumer has the possibility to see in advance what the chosen items would look like. Such solution reduces also the risk of after-purchase dissonance and increases certainty that the choice made by the consumer was right.

\section{QR codes and chatbots}

\section{1. $Q R$ codes}

An interesting graphic form used in marketing are QR (Quick Response) codes, called also photo-codes. QR codes are two-dimensional, and the data are coded using the contrast (not necessarily black-and-white) modules, that correspond to $0-1$ system. Most often the codes are created to transmit some data in a creative way: Internet page, Facebook profile, Instagram, etc. (codes are then a form of a "footnote"), contact data (calling card, from which the data can be transferred instantly to the telephone memory or to the address book), events (basic information is coded, automatic transfer of the event to the smartphone calendar is possible), e-mail/ SMS (after scanning the code, the e-mail/SMS message is automatically generated including the sender, it requires only to confirm sending - this function is useful in accepting registrations for competitions), or Wi-Fi network data. QR codes are widely applied in marketing activities of enterprises, mainly to transmit marketing communications and promotion campaigns in shops.

In Poland, when making grocery shopping, one can more and more frequently see the QR code. Their use is diverse, in the simplest form they lead to the producer's homepage, but sometimes they refer to specially prepared content. An example is FRoSTA, the company selling frozen vegetables and ready foodstuffs. It has placed QR codes on packages, after scanning they display on the telephone screen the list of recipes for dishes containing individual vegetables ${ }^{4}$. The user can choose one of several dozen recipes, and then display the list of other products necessary to prepare the dish.

Another example can be the use of QR codes in product promotion by Guinness company. The code has been printed on a beer glass and incorporated into a broader design that creates an aesthetic whole. It is activated when using the product (Figure 3 ).

${ }^{4}$ FRoSTA package with QR code: http://www.frostablog.de/wpcontent/uploads/2010/10/toskana RS_rgb_klein1.jpg (access: 23.02.2017). 


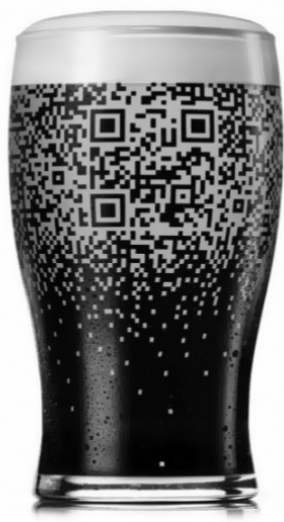

Figure 3. Creative utilization of QR code - Guinness brand

Source: http://mediapolisinteractive.pl/index.php/2012/05/28/qr-kody-a-media-ambientowe-ciekawe-przyklady-zastosowania-qr-kodow-w-marketingu/ (access: 17.02.2017).

Only white elements of QR code have been printed, so to get the contrast necessary to read it the glass should be filled with very dark liquid (such as Guinness). Those who would try to scan the code drinking light beer will not be successful. Scanning the code in appropriate circumstances sends the customer to the page with information on Guinness products ${ }^{5}$.

\subsection{Chatbots}

Chatbots are special computer software aimed at making conversation with the user. Their functioning is based on artificial intelligence. Chatbots are most often used to present the offer to customers and to answer most frequently asked questions. In the era of the Internet, accessible to its users 24 hours a day, chatbots are the best solution that allows full service, irrespectively of the time of the day. Four generations of chatbots can be distinguished:

1. Communication chatbots, that serve primarily to send information on products, services, and the enterprise functioning.

2. Second generation chatbots, defined as algorithmic, that appear in the form of avatar. They can keep conversation with the users. Apart from the functionality of the first generation chatbots, they are able to give advice during the purchase process, present alternative options, and also monitor the whole process of order realization.

3. Interactive chatbots, being the third generation bots, can recognize human speech. It is expected that in the future they will be able to serve consumers

5 Information on QR codes: http://marketinglink.pl/7-kreatywnych-sposobow-na-stworzenie-koduqr/ (access: 17.11.2016). 
completely, solving all problems 6 . In Poland, chatbots are used mainly by big enterprises, banks and public institutions.

4. Holographic chatbots which are utilized for servicing clients in shops and public service places (e.g. airports).

The name "chatbot" is currently the name of the most popular virtual advisor on the Internet. Other bot variants can be also found on the Internet, they are (according to aibotworld.com): knowbot (bot to gather, manage and give access to the knowledge); lingubot (bot intended to keep conversation with the client, to initiate dialogue and interaction); mindbot (bot to assist problem solution basing on introduced data), and shopbot (bot to assist sale in an Internet shop).

An example of chatbot application in marketing communication is the Orange company. It has put in motion the Virtual Advisor Ewa on its own www page (Figure 4). Besides the extensive base of issues connected with customer service, this chatbot is able to answer a number of other questions ${ }^{7}$.

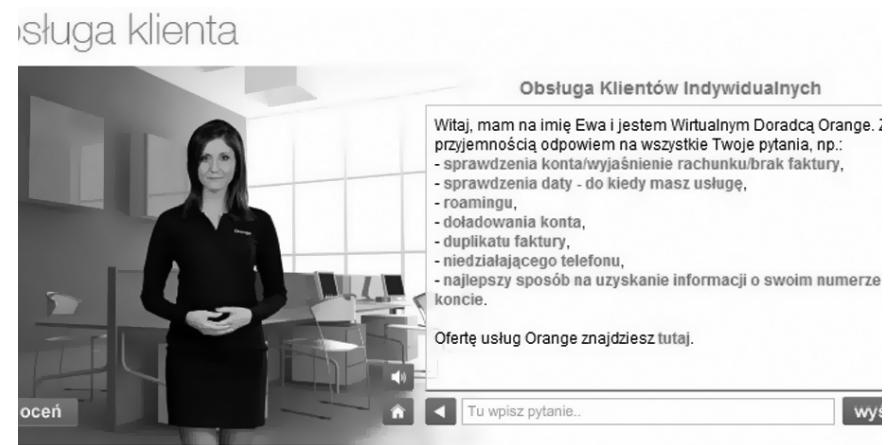

Figure 4. Virtual Orange Advisor - Ewa

Source: http://www.stanusch.com/smartweb/pk-home/stanusch/upload/klienci/orange1.jpg (access: 21.02.2017).

The communication is textual, but the introduction of chatbot increases the quality of customer service and decreases the costs connected with promotional activities of the company. As for the advanced chatbots, the leader in Poland is Stanusch Technologies ${ }^{8}$. This company creates technologies based on the artificial intelligence that allow one to automatically give precise answers to any enquiries of employees, clients of companies or institutions?.

6 A. Dejnaka, Proces podejmowania decyzji zakupowych przez e-konsumentów w kontekście mediów społecznościowych, CeDeWu, Warszawa 2013, pp. 71-74.

7 Chatbot Ewa: https://www.chatbots.org/virtual_assistant/ewa21/(access: 21.05.2015).

8 Stanusch Technologies received the title of the most innovative product in the contest "National Leaders of Innovation and Development 2010", http://www.liderzyinnowacji.pl/ (access: 03. 12.2016).

9 Chatbots of Stanusch Technologies are carefully prepared not only concerning information technology, but also "human qualities". When chatbot has no contact with the client, it "becomes bored" calls friends, tries to call partner's attention, drinks coffee. It emanates empathy. 


\section{360-degree multimedia}

360-degree films/multimedia, also called spherical films, are new image technology applied in marketing communication. The viewer is situated as though "inside the film" and decides him/herself which part of the image will be observed and when. The main merit of such marketing materials for the customer is the possibility to freely look around - the movie can be rotated, giving any angle of view. In normal 2D, or even 3D film, the viewer sees the picture being suggested by the cameraman or director. In contrast, in 360-degree films, all areas can be observed, even those not discovered yet. We can observe not only the movie action, but also everything around.

The most immerse way that gives really interesting experiences is watching a 360-degree film using goggles for virtual reality, e.g. Google Cardboard or Samsung Gear VR. Additionally, in simplified version for smartphones with Android system, there appeared many applications that allow one to watch 306-degree movies without VR goggles, like Go VR and VR Media Player.

Effective and compatible with the newest trends marketing (promotion) material should include:

- the use of drones in taking shots;

- material filmed in 360-degree video technology;

- enriching the material with 3D visualization in the virtual reality (AR).

360-degree films/multimedia are the challenge, new trend, and, in fact, the future of world imaging and marketing promotions. Using this technology, both advertising and promotional materials as well as company image materials are done.

\section{The Internet of Things, wearable technology and "smart \& simply" technology}

In contemporary marketing activities, an increasing number of companies makes use of technologies, knowing that the society follows what is innovative, and best of all - mobile. New trends show that technologies like the Internet of Things, wearable technology and "smart \& simply" one draw increasing attention of marketing.

\subsection{The Internet of Things}

The Internet of Things (IoT) is a concept according to which things can directly or indirectly collect, process or exchange data using the computer network. This trend, the popularity of IoT and mobile appliances, has been strategically utilized in IKEA company. It decided to create furniture integrated with the technology of wireless charging the mobile appliances and wireless chargers (Figure 5).

These new IKEA products are mostly tables and lamps integrated with wireless chargers and stands where one or a number of smartphones can be charged at the same time. These stands have an additional USB slot. IKEA chargers are working on the base of Qi technology and are compatible with other appliances using this software. 

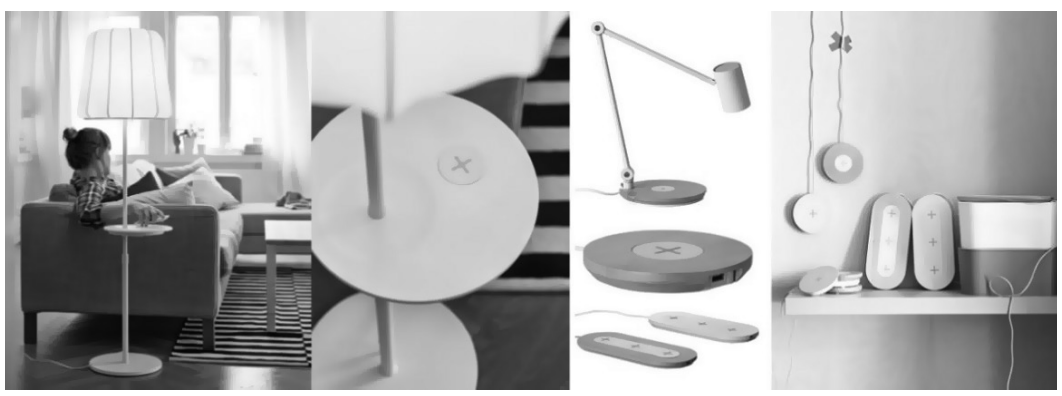

Figure 5. Internet of Things - IKEA

Source: http://www.wirtualnemedia.pl/artykul/ikea-zaoferuje-meble-ladujace-urzadzenia-mobilne (access: 02.02.2017).

\subsection{Wearable technology and "smart \& simply" technology}

Wearable technology means intelligent products, like intelligent bands, glasses, watches. The aim of wearable technologies is, first of all, to gather data that will be used for the purposes defined by the user. More and more recognized are bands that collect information on physical activity, pulse, or sleep quality of their users. Moreover, appliances from the wearable technology line, besides collecting data, quite often ease also the everyday life (e.g. allow one to make payments). Developments in wearable technologies are limited only by human imagination. According to "Forbes", the market for wearable technologies in Central and Eastern Europe has noted the increase by $78.7 \%$ in the first quarter of 2016 (328 thousand appliances). The majority of sales are still the simple bands and accessories. Analytics forecasts multiple increase of this business up to 2020. An example of wearable technology is the elastic women's bracelet integrated with a smartphone (Figure 6).

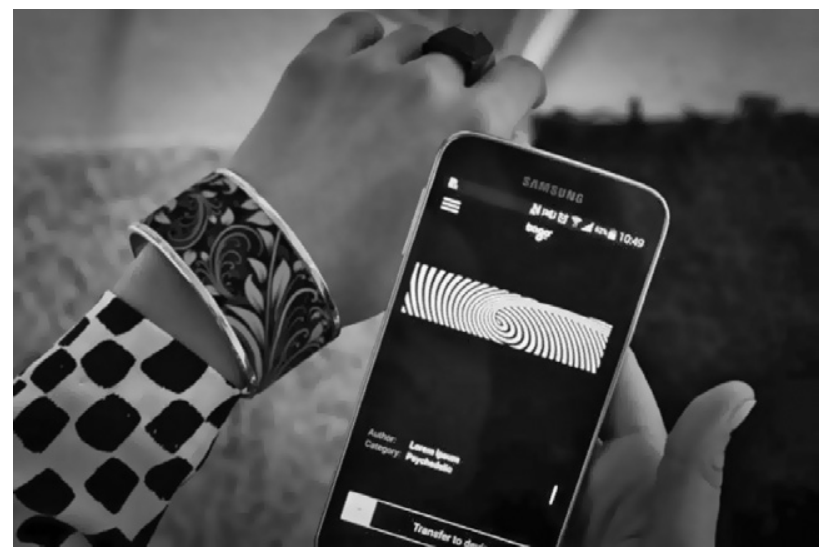

Figure 6. Elastic women's bracelet integrated with a smartphone

Source: http://www.forbes.pl/technologia-ubieralna-coraz-bardziej-popularna,artykuly,205753,1,1,1.html\# (access: 12.02.2017). 
Not only telephones and watches can be "smart \& simply". Any product can be granted specific intelligence, e.g. a bottle of exclusive whisky - Johnnie Walker. An intelligent bottle is equipped with an electronic element with NFC (Near Field Communication) module. When the smartphone with an installed, dedicated application is moved closer, the bottle can communicate. Messages being sent are primarily promotional offers, coupons, or drink recipes. Moreover, the bottle is capable to assess if it has been opened or not. If the consumer has not opened it yet, promotional offers (maybe consumer is still in the shop and considers the purchase) with the encouragement to open will be sent, while after the opening there will be drink recipes.

\section{Conclusions}

Today's technologies offer many possibilities, while marketing and sale are very actively looking for another forms of getting access to the client. Customers are no more interested in traditional forms of marketing message, so any originality and innovativeness positively influences the company's image and allows one to remember the brand/message sender. New trends in technologization of marketing communication are only novelties now, but in the future, they will become - according to the author - part of everyday life. The use of modern technologies in marketing communication makes an important trump concerning the appeal of message addressed to the audience. On the other hand, however, care should be taken not to make the technologization of marketing an end in itself, just to show the technology, disrespecting, at the same time, the needs of message receivers - one of which is the normal need to be among other people and to communicate directly with another person.

\section{Bibliography}

Bonsor, K., How Augmented Reality Will Work, http://computer.howstuffworks.com/augmented-reality. htm (access: 02.02.2017).

Burns, M., Bitner, T., Sztuka informowania, "Digit", no. 6, 2011.

Dejnaka, A., Proces podejmowania decyzji zakupowych przez e-konsumentów w kontekście mediów społecznościowych, Wydawnictwo CeDeWu, Warszawa 2013.

http://www.augmentedrealitytrends.com/augmented-reality-retail/will-augmented-reality-change-the-future-of-retail-market-part-1.html (access: 17.02.2017).

http://www.chatbots.org/virtual_assistant/ewa21/ (access: 21.05.2015).

http://www.dezeen.com/2013/08/05/ikea-launches-augmented-reality-catalogue/ (access: 17.02.2017)

http://www.frostablog.de/wpcontent/uploads/2010/10/toskana_RS_rgb_klein1.jpg (access: 23.02.2017).

http://www.liderzyinnowacji.pl/ (access: 03. 12.2016).

http://marketinglink.pl/7-kreatywnych-sposobow-na-stworzenie-kodu-qr/ (access: 17.11.2016).

http://mediapolisinteractive.pl/index.php/2012/05/28/qr-kody-a-media-ambientowe-ciekawe-przyklady-zastosowania-qr-kodow-w-marketingu/ (access: 17.02.2017).

http://www.newsfix.pl/2011/05/20/augmented-reality-i-jej-zastosowania-przez-zwyklych-uzytkownikow/ (access: 20.01.2017). 
http://www.salesnews.pl/SalesSupportArticle.aspx?id=32 (access: 17.02.2017).

http://www.stanusch.com/smartweb/pk-home/stanusch/upload/klienci/orange1.jpg (access: 21.02.2017). http://www.wirtualnemedia.pl/artykul/ikea-zaoferuje-meble-ladujace-urzadzenia-mobilne (access: 02.02.2017).

http://www.forbes.pl/technologia-ubieralna-coraz-bardziej-popularna,artykuly,205753,1,1,1.html\# (access: 12.02.2017).

Newsom, D., Haynes, J., Public Relations Writing: Form and Style, Thompson, Wadsworth 2008.

\section{Technologization of Marketing Communication - New Trends}

Dynamic changes can now be observed both in Internet activities and in marketing communication. The article deals with new trends in technologization of marketing communication, including the use of augmented reality, QR codes, chatbots, the Internet of Things and "smart \& simple" technology. In addition, the latest trends in image marketing/communication and image/video 360-degree communication will be presented. The article is based on the analysis of trends in technology-based communication and critical analysis of applications.

\section{Technologizacja komunikacji marketingowej - nowe trendy}

Dynamiczne zmiany widoczne są obecnie zarówno w działaniach internetowych, jak i komunikacji marketingowej. Artykuł dotyczy nowych trendów w technologizacji komunikacji marketingowej, m.in. wykorzystania w komunikacji rzeczywistości rozszerzonej, kodów $Q R$, chatbotów, Internetu rzeczy i technologii ,smart \& simple”. Dodatkowo zostały przedstawione najnowsze trendy w zakresie marketingu obrazkowego (komunikacji obrazkowej) oraz komunikacji obrazkowej/video - 360 stopni. Artykuł został oparty na analizie trendów w komunikacji bazującej na technologiach oraz na analizie krytycznej zastosowań. 